Creative commons User License: CC BY-NC-ND

Abstracted by: EBSCOhost, Electronic Journals Service (EJS),

Google Scholar, Journal Seek, Scientific Commons,

Food and Agricultural Organization (FAO), CABI and Scopus
Journal of Agricultural Extension

Vol. 22 (1) February, 2018

ISSN(e): 24086851; ISSN(Print); 1119944X

http://journal.aesonnigeria.org

http://www.ajol.info/index.php/jae

Email: editorinchief@aesonnigeria.org

\title{
Food Security and Productivity among Urban Farmers in Kaduna State, Nigeria
}

https://dx.doi.org/10.4314/jae.v22i1.15

\section{Saleh, M.K.}

Department of Agricultural Economics and Rural Sociology, Ahmadu Bello University, Zaria

E-mail:salequa@yahoo.com, quagyangsaleh@gmail.com

Phone: +234(0)8032949878, +234(0)8123431446

Mustafa, A.S.

Business Innovation Facility, 13, Ahmed Daku Cresent, Off Sokoto Road, Kano

E-mail:anasmustafa2000@yahoo.com, mustafa.anas@cbinigeria.org

Phone: $+234(0) 08036012653$

\section{Abstract}

This study to investigated food security and productivity among urban farmers' in Kaduna State Two-stage sampling procedure was used to select 213 respondents for the study. Interview schedule was used to collect data. Data were analysed using descriptive statistics (food security index, food insecurity/ surplus gap index and productivity index) and multiple regression model. The results show that $54.5 \%$ of the households were food insecure. The average daily per capita calorie intake for food secure households was $65516.28 \mathrm{kcal}$. The mean age of the respondents was 46 years old, $46 \%$ had tertiary education and average farm size was 1.25 ha. Regression model predicted food security status at $70.3 \%$ accuracy with MacFadden $R$-square of 0.13 . This implies that all variables were able to explain $64 \%$ of the variation in food security status of the households, implying that on average, the probability of urban farming households will be food secure at $51 \%$. The log-likelihood was significant at $1 \%$ and the average marginal effect was 0.51 . All the variables included were able to explain $64 \%$ of the variation in food security status of the households. Therefore, it recommended that viral extension services and appropriate measures to be implemented to change behaviour of urban farmers and boost their productivity, thereby reducing food insecurity and increase income of urban farmers in the area.

Keywords: Food security, urban agricultural productivity, farming household. 
Creative commons User License: CC BY-NC-ND

Abstracted by: EBSCOhost, Electronic Journals Service (EJS),

Google Scholar, Journal Seek, Scientific Commons,

Food and Agricultural Organization (FAO), CABI and Scopus
Journal of Agricultural Extension

Vol. 22 (1) February, 2018

ISSN(e): 24086851; ISSN(Print); 1119944X

http://journal.aesonnigeria.org

http://www.ajol.info/index.php/jae

Email: editorinchief@aesonnigeria.org

\section{Introduction}

Food is a basic necessity of life and means of sustenance. Adequate food intake in quantity and quality is a key factor for healthy, productivity and peaceful living. Its shortage often results to conflicts, even full blown war, as the saying, 'a hungry man is an angry man'. In Nigeria, food accounts for a substantial part of household budget (Omonona and Agoi, 2007). Meeting the food demands requires some consented efforts in agricultural sub-sector of the economy to carter for the rapidly growing population in country. This situation calls for deliberate approach of improving unused open spaces of land in urban centres for agricultural production. The approach is necessary in view of the failure of the domestic agricultural sub-sector in the rural areas to provide sustainable food for Nigerians. The decline is obvious due to various conflicts such as Boko Haram insurgency in the North-East, Fulani terrorism in the North Central and North-west and militant groups in Niger Delta. This probably explains why Otu, et al.(2014) stated that urban centres are becoming larger and further separated from food and it is showing increasing problems of food insecurity and its ensuing conflicts. Urban agriculture is being explored by this study is design to assess food insecurity and conflicts situations in urban centres because it has the capacity to engage the teeming unemployed urban youth in productive vocations in different aspects of agro-allied ventures for the benefit of all.

By definition, food security is a condition in which all people at all times can acquire safe, nutritionally adequate and personally acceptable foods in a manner that maintains human dignity (Adewuyi, 2012). Food security demands that food producers and processors shall be enabled to earn a fair return on their labour and that those food production and processing methods should be sound enough to sustain the humans and their environment in a congenial manner (Otu, et al., 2014). Thus, Entrepreneurial urban agriculture is steering urban centres to a new, exciting and different urban society where human beings and their environment live in harmony. In this regard, a farming economy within the parameters of an urban centre would be a dramatic new way that urban centres view themselves as primary food producing centres, not just consuming centres. In recent times, urban agriculture has gained importance basically because it has been discovered to be a viable intervention strategy for the urban poor to earn extra income thereby reducing criminal tendencies and increasing self-reliance in food produce by oneself and cash income from the extra food grown on unused land (Egbuna, 2014).

Most food consumed in urban centres is purchased and poor urban families spend between $60 \%$ and $80 \%$ of their monthly incomes on food (Muhammad-Lawal and Atte, 2006). The current reality in Nigeria is that poor urban families spend between $80 \%$ and $85 \%$ of their income on food. Therefore, ability to grow part of food consume by poor urban families and earn extra cash income are significant determinants of food security, conflict and poverty reduction. This is because food has become one of the biggest 
Creative commons User License: CC BY-NC-ND

Abstracted by: EBSCOhost, Electronic Journals Service (EJS),

Google Scholar, Journal Seek, Scientific Commons,

Food and Agricultural Organization (FAO), CABI and Scopus
Journal of Agricultural Extension

Vol. 22 (1) February, 2018

ISSN(e): 24086851; ISSN(Print); 1119944X

http://journal.aesonnigeria.org

http://www.ajol.info/index.php/jae

Email: editorinchief@aesonnigeria.org

challenges that poor urban dwellers face in Nigeria. The majority of them work in sectors where wages are low, working conditions are precarious and job tenure insecure. Otu, et al. (2014) revealed that employment in urban agriculture accounts for not less than $10 \%$ of total employment in sub-Sahara Africa.

The vision of Nigeria to have physical and economic access to food on a continuous basis will remain a mirage. According to available statistics, as at 1986, about 14 million $(16 \%)$ Nigerians were food insecure with the majority being peasant urban households (Fakayode et al., 2009; Abalu, 1999). In 2007, over $40 \%$ of households across Nigeria face the problem of severe food insecurity (Fakayodeet al., 2009). The 2010 Millennium Development Goal (MDG) reported that the proportion of the Nigerian population living below the hunger threshold has increased from 29\% to 33\% between 2000 and 2009, and the target set for achieving $14.5 \%$ food increase by 2015 had remained elusive to date.

Several studies have been carried out on food security in Nigeria, they included: Omonona and Agoi (2007); Adeyemo and Kuhlmann (2013); Fakayodeet al. (2009) and Idrisa, Gwary and Shehu, 2008). Most of these studies have focused on measuring food security using the consumption expenditure, analysing food security among urban poor households and suggesting ways of solving the food problem. However, little studies have been done on analysing entrepreneurial and productivity behaviour of urban farmers; hence, this study was carried out to fills this gap. The objectives of this study were to evaluate socio-economic characteristics of urban farmers, their income from urban agriculture, productivity, food security and constraints of urban agriculture in the Kaduna State.

\section{Methodology}

The study was conducted in Kaduna North, Kaduna South, Jema'a, Zaria and Sabon Gari Local Government Areas of Kaduna State, Nigeria. The study took place during 2014/2015 farming season in five urban local government areas (LGAs) of the State. Three communities were randomly selected from each local government, making 15 out of 30 communities identified. The sampling frame for the study comprised all urban farming households who cultivate crops, vegetables and keep livestock.

A two stage sampling procedure was used for the study. In the first stage, purposive sampling of seven urban LGAs was carried out. In stage two, the seven LGAs were randomly selected. The same procedure was carried out in the second stage using random sampling technique to select farmers in each urban centres for the study. The five urban areas selected were Kaduna North, Kaduna South, Jema'a, Zaria and SabonGari. A total of 426 urban farmers were identified in the study area and $50 \%$ (213) were selected for questionnaire administration. The data were obtained from 213 urban farmers was by the use of structured interview schedule. 
Creative commons User License: CC BY-NC-ND

Abstracted by: EBSCOhost, Electronic Journals Service (EJS),

Google Scholar, Journal Seek, Scientific Commons,

Food and Agricultural Organization (FAO), CABI and Scopus
Journal of Agricultural Extension

Vol. 22 (1) February, 2018

ISSN(e): 24086851; ISSN(Print); 1119944X

http://journal.aesonnigeria.org

http://www.ajol.info/index.php/jae

Email: editorinchief@aesonnigeria.org

\section{Measuring Food Security}

The FAO recommended minimum daily energy requirement per adult equivalent is 2250 $\mathrm{kcal}$, therefore, this value defines the food security line for this study. Households which are below the food security line are classified as food-insecure households, while those households that are above are classified as food-secured households (FAO, 2011).

Aggregation on the other hand involves estimating the daily per capita calorie consumption of each household. The study adopted the estimated daily calorie supply of the household, divided by the household size adjusted for adult equivalents using the consumption factor for age - sex categories in Table 1a. Household calorie supply was estimated using food nutrient composition in Table 1b.

Thus,

Food security index $(\mathrm{z})=\frac{\text { House hold's daily per capita calorie supply }}{\text { Recommended daily per capita calorie requirement }}$

In addition, food insecurity gap index, food surplus gap index and the headcount ratio of food security were calculated for the sampled households based on the food security index (Z). The food insecurity gap (P) measures the extent to which food insecure households on average fall below the food security line and the food surplus gap (S) measures the extent by which food secure households exceeded the food security line. The Headcount index $(\mathrm{H})$ measures the percentage of sampled household that are food insecure/secure. The Head count ratio, food insecurity gap and food surplus gap is defined as:

- Headcount index $\left(\mathrm{H}_{\mathrm{fi}}\right)=\frac{M}{N}$

- Headcount index $\left(\mathrm{H}_{\mathrm{fs}}\right)=\frac{L}{N}$

- Food insecurity gap index $(\mathrm{P})=\frac{1}{M} \sum_{i=1}^{m}$ where $\mathrm{G} i=\frac{Y i-R}{(R)}$

- Food surplus gap index $(\mathrm{S})=\frac{1}{L} \Sigma_{i}^{L}=1$ where $\mathrm{G} i=\frac{Y i-R}{(R)}$

Where:

$M=$ number of food insecure households;

$\mathrm{N}=$ total number of households in the sample;

$\mathrm{L}=$ number of food secure households;

$G_{i}=$ daily per capita calorie deficiency or surplus for ith household;

$\mathrm{H}_{\mathrm{fs}}=$ headcount index for food secured households;

$\mathrm{H}_{\mathrm{fi}}=$ headcount index for food insecure households;

$Y_{i}=$ daily per capita calorie consumption on food item of $i_{\text {th }}$ households;

$\mathrm{R}=$ recommended daily per capita calorie requirement. 
Creative commons User License: CC BY-NC-ND

Abstracted by: EBSCOhost, Electronic Journals Service (EJS),

Google Scholar, Journal Seek, Scientific Commons,

Food and Agricultural Organization (FAO), CABI and Scopus
Journal of Agricultural Extension

Vol. 22 (1) February, 2018

ISSN(e): 24086851; ISSN(Print); 1119944X

http://journal.aesonnigeria.org

http://www.ajol.info/index.php/jae

Email: editorinchief@aesonnigeria.org

\section{Measuring Productivity}

To assess the productivity of urban farmers, the following productivity index was used.

Productivity $=\frac{\text { Total output of crops produce (value in naira) }}{\text { Total cost of variable input used in production (Naira) }}$

To determine the effect of urban food crop farming household productivity on household food security, the logistic regression model was estimated. The implicit form of the model is expressed as:

$Z i=\beta X i+U$

(6)

$\mathrm{Zi}=$ Household food security status (food secure households $=1$, food insecure households $=0$ )

$\mathrm{Xi}=$ Vector of explanatory variables

$\mathrm{U}=$ Error term

$\beta=$ Vector of the parameter estimates

$X=$ explanatory variables and are defined as follows:

$\mathrm{X} 1$ = Productivity of urban food crop farmers,

$\mathrm{X} 2$ = Farm size (ha),

$\mathrm{X} 3=$ Labour (mandays),

X4 = Capital (number of farm equipments own).

\section{Results and Discussion}

\section{Socio-economic Characteristics of the Farmers}

The study found that the average age of the farmers was 46 years. This finding agrees with that of Liverpool-Tasie, Kuku and Ajibola (2011) which reported that productive farmers were generally in their middle age. The majority (82.0\%) was married and had a mean average of 7 members in their households. This finding is in agreement with the one reported by Diriba (2015) who stated that farmers with fairly large family size has the potentials for labour force and sources of information on agricultural innovation. Many (46.0\%) of the respondents had tertiary education, with a mean of 18 years of schooling. The mean farming experience of the respondents was 8 years. This result is in agreement with Blaikie, Cannon, Davis and Wisner (2011) who found that farmers' education has positive relationship with entrepreneurial behaviour. Some $(31.0 \%)$ of the respondents had farm size of less than 1 ha., $30.0 \%$ had between 1-1.5ha. of farm land and $7.0 \%$ had above 3ha. Extension services were generally low with an average 3 contacts per year (Table 1). 
Creative commons User License: CC BY-NC-ND

Abstracted by: EBSCOhost, Electronic Journals Service (EJS),

Google Scholar, Journal Seek, Scientific Commons,

Food and Agricultural Organization (FAO), CABI and Scopus
Journal of Agricultural Extension

Vol. 22 (1) February, 2018

ISSN(e): 24086851; ISSN(Print); 1119944X

http://journal.aesonnigeria.org

http://www.ajol.info/index.php/jae

Email: editorinchief@aesonnigeria.org

Table 1: Distribution of respondents by socio-economic characteristics

\begin{tabular}{|c|c|}
\hline Variable & Per cent \\
\hline \multicolumn{2}{|l|}{ Age (yrs) } \\
\hline$<15$ & 2 \\
\hline $15-19$ & 13 \\
\hline $20-24$ & 17 \\
\hline $25-29$ & 11 \\
\hline $30-34$ & 6 \\
\hline $35-39$ & 18 \\
\hline $40-44$ & 14 \\
\hline $45-49$ & 9 \\
\hline $50-54$ & 3 \\
\hline $55-50$ & 5 \\
\hline $60+$ & 2 \\
\hline \multicolumn{2}{|c|}{ Marital status (yes or no) } \\
\hline Married & 82 \\
\hline Single & 5 \\
\hline Widower & 8 \\
\hline \multicolumn{2}{|c|}{ Household size (persons) } \\
\hline $1-5$ & 24 \\
\hline $6-10$ & 54 \\
\hline $11-15$ & 12 \\
\hline $16+$ & 10 \\
\hline \multicolumn{2}{|c|}{ Educational status (yrs) } \\
\hline Illiterate & 6 \\
\hline Adult education & 14 \\
\hline Primary school & 30 \\
\hline Secondary school & 4 \\
\hline Tertiary education & 46 \\
\hline \multicolumn{2}{|c|}{ Farming Experience (yrs) } \\
\hline $1-5$ & 28 \\
\hline $6-10$ & 32 \\
\hline $11-15$ & 8 \\
\hline $16-20$ & 10 \\
\hline $21+$ & 22 \\
\hline \multicolumn{2}{|l|}{ Farm size (ha.) } \\
\hline$<1$ & 31 \\
\hline $1-1.5)$ & 30 \\
\hline $1.6-2)$ & 6 \\
\hline $2.1-2.5$ & 11 \\
\hline $2.6-3$ & 15 \\
\hline $3+$ & 7 \\
\hline \multicolumn{2}{|c|}{ Extension contact (No. of visit in a yr) } \\
\hline Once & 22 \\
\hline Twice & 30 \\
\hline Thrice & 24 \\
\hline Four times & 24 \\
\hline
\end{tabular}


Creative commons User License: CC BY-NC-ND

Abstracted by: EBSCOhost, Electronic Journals Service (EJS),

Google Scholar, Journal Seek, Scientific Commons,

Food and Agricultural Organization (FAO), CABI and Scopus
Journal of Agricultural Extension

Vol. 22 (1) February, 2018

ISSN(e): 24086851; ISSN(Print); 1119944X

http://journal.aesonnigeria.org

http://www.ajol.info/index.php/jae

Email: editorinchief@aesonnigeria.org

\section{Food security among farming households}

Table 2 shows that $54.5 \%$ of the households were food insecure. This result agrees with Idrisa et al. (2008) that more than half of the households in the study were not food secured. The average daily per capita calorie intake in the study area was 3,175.72 $\mathrm{kcal}$. This is higher than the recommended minimum daily calorie of 2,250 recommended by FAO and also higher than the national average of 2,700 kcal as reported by Babatunde et al. (2007). However, the average daily per capita calorie intake for food secure household was $5,516.28 \mathrm{kcal}$, which is higher than both the FAO and national average. The average daily per capita calorie intake of food insecure households was $835.15 \mathrm{kcal}$, which is far lower than both the FAO and national average. The study area could therefore be regarded as food insecure given to the fact that $45.5 \%$ of the population was able to meet the recommended calorie intake of 2,250 kcal per capita per day. The food insecurity gap and surplus index which measures the extent of deviation from food security line shows that food secure households exceeded the calorie requirement by $145 \%$, while the food insecure households fell short of the calorie requirement by $91 \%$. This shows a gap between the food secure and food insecure households in the study area.

Table 2: Indices of farming household food security

\begin{tabular}{|c|c|c|c|}
\hline Food Security Indices & $\begin{array}{l}\text { Food Insecure } \\
\text { Households }\end{array}$ & $\begin{array}{l}\text { Food Secure } \\
\text { Households }\end{array}$ & All \\
\hline Number of households & 116 & 97 & 213 \\
\hline Percentage of households & 54.5 & 45.5 & 100 \\
\hline $\begin{array}{l}\text { Mean of household size (adult } \\
\text { equivalent) }\end{array}$ & 9.0 & 7.0 & 8.0 \\
\hline $\begin{array}{l}\text { Food security index }(Z) \text { : } \\
\text { Mean }\end{array}$ & 0.29 & 3.63 & 1.97 \\
\hline Std & 0.038 & 0.21 & 0.12 \\
\hline $\begin{array}{l}\text { Mean households daily } \\
\text { calorie consumption(kcal) }\end{array}$ & 870.29 & 8811.23 & $\begin{array}{l}5,275 . \\
91\end{array}$ \\
\hline $\begin{array}{l}\text { Mean household per capita } \\
\text { daily consumption(kcal) }\end{array}$ & 835.15 & $5,516.28$ & $\begin{array}{l}3,175 \\
72\end{array}$ \\
\hline $\begin{array}{l}\text { Food insecurity } \\
\text { gap }(\mathrm{P}) / \text { surplus index(S) }\end{array}$ & 0.91 & 1.45 & - \\
\hline Head count ratio $(\mathrm{H})$ & 0.55 & 0.48 & - \\
\hline
\end{tabular}

\section{Constraints of Urban Farming}

The result presented in Table 3 shows that urban farmers encountered constraints while practicing urban agriculture in the area. More than one-third (36.0\%) reported land scarcity in the area, $24 \%$ pests and diseases, $16.0 \%$ high prices of veterinary drugs and $4 \%$ urban pollution. 
Creative commons User License: CC BY-NC-ND

Abstracted by: EBSCOhost, Electronic Journals Service (EJS),

Google Scholar, Journal Seek, Scientific Commons,

Food and Agricultural Organization (FAO), CABI and Scopus
Journal of Agricultural Extension

Vol. 22 (1) February, 2018

ISSN(e): 24086851; ISSN(Print); 1119944X

http://journal.aesonnigeria.org

http://www.ajol.info/index.php/jae

Email: editorinchief@aesonnigeria.org

Table 3: Distribution of constraints of urban farming

\begin{tabular}{ll} 
Constraint & Per cent \\
\hline Pests and disease & 24 \\
Urban land use law & 4 \\
Water scarcity & 8 \\
Urban pollution & 4 \\
Land scarcity & 36 \\
High price of veterinary dugs & 16 \\
Access to Bank loans & 8 \\
\hline
\end{tabular}

\section{Factors Affecting Entrepreneurial and Productivity Behaviour of Urban Farmers}

Table 4 shows that the model predicted the food security status of urban farming households with $70.3 \%$ accuracy. The MacFadden R-square of 0.13 implies that all the explanatory variables included in the model were able to explain $64 \%$ of the variation in food security status of the households. The log-likelihood ratio (LR) test is significant at $1 \%$ level of probability, meaning that the model is adequate in explaining the probability of the effect of the explanatory variables on household food security status. The average of marginal effect is 0.51 , implying that on the average, the probability that urban food crop farming households will be food secure is $51 \%$ assurance.

The empirical results of the study revealed that the coefficient of the productivity of urban farming households had positive and significant effect at $1 \%$ level of probability. The marginal effect value of 0.10 suggests that, if the productivity of urban farming households is increased by one unit, the probabilities of households being food secure increases by $100 \%$. This indicates that the higher the productivity of urban farming household, the higher is the probability that households would be food secure. This result agrees with the work of Liverpool-Tasieet al., (2011) who found that agricultural productivity affects food security directly by increasing the available supply of food, particularly for subsistence households, and indirectly by increasing incomes.

Farm size also had positive and significant effect at $1 \%$ level of probability. The marginal effect value of 0.04 implies that, if farm size increases by one unit, the probability that urban farming households would be food secure by $4 \%$. This means that, the larger the farm size, the more likely urban food crop farming households would be food secure.

Social participation had positive and significant effect at $5 \%$ level of probability. The marginal effect value of 0.01 implies that if labour used in man-day increases by one unit, the probability of households being food secure increases by $10 \%$. 
Creative commons User License: CC BY-NC-ND

Abstracted by: EBSCOhost, Electronic Journals Service (EJS),

Google Scholar, Journal Seek, Scientific Commons,

Food and Agricultural Organization (FAO), CABI and Scopus
Journal of Agricultural Extension

Vol. 22 (1) February, 2018

ISSN(e): 24086851; ISSN(Print); 1119944X

http://journal.aesonnigeria.org

http://www.ajol.info/index.php/jae

Email: editorinchief@aesonnigeria.org

Table 4: Effect of entrepreneurial and productivity behaviour of urban farmers

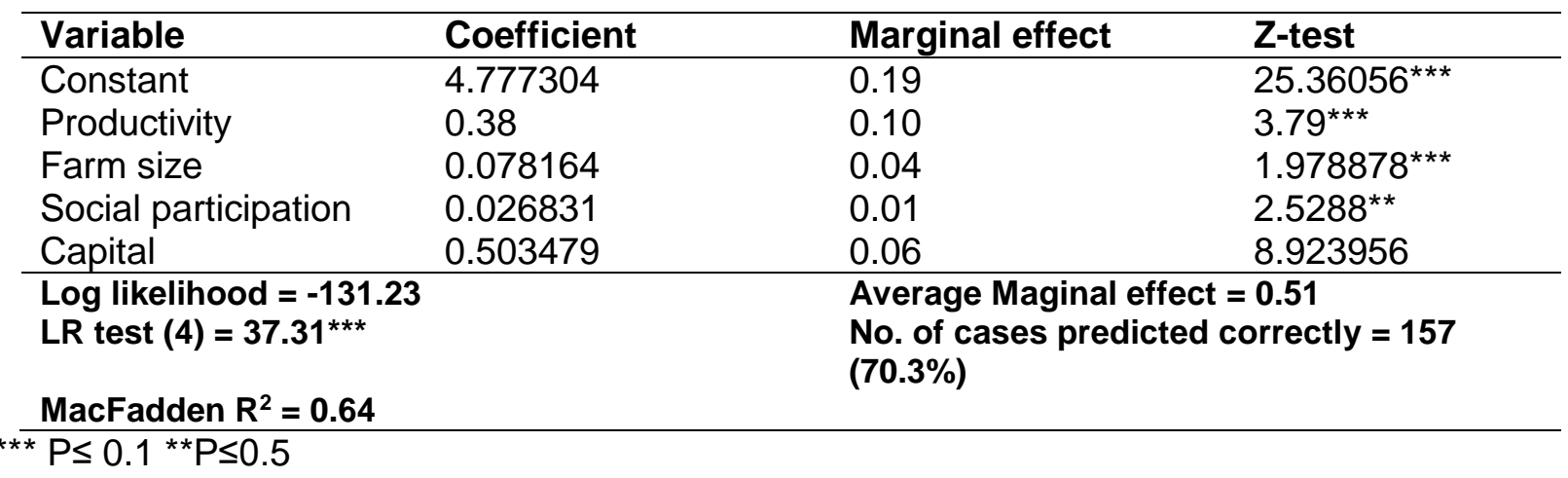

\section{Conclusion and Recommendation}

Urban farming is a profitable practice with tremendous upward movement from lower income earning groups to higher groups. Nevertheless, the majority of the farmers in the area were food insecure. Also, the productivity of urban farming households had a significant and positive effect on food security status of the respondents.

There is the need for mass sensitization through virile extension services to mobilise urban dwellers to understand the potential of urban farming to combat food insecurity in the country. Higher the productivity of urban farming households means higher income and profit and higher would be the chance of food secure urban farmers. Measures such as intensification of using new inputs and improved technologies in farming at affordable prices to the farmers should be implemented by government at all levels. Pests and diseases were among the constraints of the respondents, urban authorities should make pesticides and veterinary drugs to farmers at affordable prices.

\section{References}

Abalu, G. O. I. (1999). The attainment of food security in Nigeria: The Role of Resource Constrained in Nigeria Farmers. In O. Oluwasola (Ed), Implications of Peasant Agricultural Practices for Environmental Resources, Food Security and Agricultural Sustainable Development in Nigeria.Poverty Alleviation and Food Security in Nigeria. NAAE 197-206. National Farming Systems Research Nigeria, Ibadan Network Bulletin.

Adewuyi, S. A. (2012). Resource Use Productivity in Food Crop Production in Kwara State, Nigeria. Unpublished PhD Thesis, Department of Agricultural Economics, University of Ibadan, Nigeria.

Adeyemo, R. and Kuhlmann, F. (2013).Resource Use Efficiency in Urban Agriculture in Southwestern Nigeria.Tropicultura, 27(1), 49-53. 
Creative commons User License: CC BY-NC-ND

Abstracted by: EBSCOhost, Electronic Journals Service (EJS),

Google Scholar, Journal Seek, Scientific Commons,

Food and Agricultural Organization (FAO), CABI and Scopus
Journal of Agricultural Extension

Vol. 22 (1) February, 2018

ISSN(e): 24086851; ISSN(Print); 1119944X

http://journal.aesonnigeria.org

http://www.ajol.info/index.php/jae

Email: editorinchief@aesonnigeria.org

Babatunde, R. O., Omotesho, O. A. and Sholotan, O. S. (2007). Factors Influencing Food Security Status of Rural Farming Households in North Central Nigeria. Agricultural Journal, 2(3), 351-357.

Blaikie, P. M., Cannon, T., Davis, I. and Wisner, B. (2011). At Risk: National Hazards, People's Vulnerability and Disasters. London and New York. Rautledge.

Egbuna, E.N. (2014). Urban Agriculture and Food Security in Abuja: An Enquiry. Unpublished Ph.D. Thesis, University of Agriculture, Abeokuta, Nigeria.

Fakayode, S. B.Rahji, M. A. Y., Oni, O. A., and Adeyemi, M. O. (2009). An Assessment of Food Security Situations of Farm Households in Nigeria: A USDA approach. The Social Sciences, 4(1), 24-29

Food and Agricultural Organisation. (2011). A Cassava Industrial Revolution in Nigeria.www.fao.org/doerep/007/y5548e/y5548e0b.htm (Accessed on January 8, 2014).

Idrisa, Y. I., Gwary, M. M. and Shehu, H. (2008). Analysis of Food Security Status among Farming Households in Jere Local Government Area of Borno State, Nigeria. Journal of Tropical Agriculture, Food, Environment and Extension, 7(3), 199-205.

Liverpool-Tasie, L. S., Kuku, O. and Ajibola, A. (2011). A Review of Literature on Agricultural Productivity, Social Capital and Food Security in Nigeria. NSSP working paper No. 21. IFPRI. Abuja.

Muhammad-Lawal, A. and Atte, O. A. (2006). An Analysis of Agricultural Production in Nigeria.African Journal of General Agriculture, 2(1), 1-6.

Omonona, B. T. and Agoi, G. A. (2007). An Analysis of Food Security Situation among Nigerian Urban Households: Evidence from Lagos State, Nigeria. Journal of Central European Agriculture, 8(3), 397-406.

Otu, W.; Ibok, L.;Idiong, C.; Idiong, T.,Nsikan, E.; Bassey, O.; and Ekaette S. U. (2014). Food Security and Productivity of Urban Food Crop Farming Households in Southern Nigeria, Journal of Agricultural Science, 2 (3): 01-12 